\title{
A Healer and Televangelist Reaching out to the Secular Swedish Public Sphere
}

\author{
STEFAN GELFGREN
}

Umeå University

\begin{abstract}
The American televangelist and healer Benny Hinn was invited to host three meetings at a Christian conference in Uppsala 2010. The hosting institution was the Swedish charismatic Christian denomination Livets Ord. Benny Hinn has been invited by them several times before, and it can be said he is popular in some parts of Christianity, but considered rather controversial in others. The invitation and the whole event spurred an online debate, mainly on blogs and Twitter, where Livets Ord and Benny Hinn were discussed and scrutinized. This article will focus on describing and analyzing how the event was perceived and evaluated, primarily in the digital media, before, during and after the event. The churches are currently attempting to reach new audiences through digital channels, and hope to support their adherents in their everyday life beyond the meetings and activities hosted at their physical church building. However, as seen in the article, entering the digital era is not always unproblematic or straightforward. What is of particular interest here is how the digital media relocate the event - how this opens up a previously closed event, and potentially flattens out and questions traditional authorities.
\end{abstract}

Keywords: Benny Hinn, Livets Ord, Twitter, Authority, Online, Digital religion, Digital humanities

The American televangelist and healer Benny Hinn was invited to host three meetings at a Christian conference in Uppsala in 24-25 July 2010. The hosting institution was the Uppsala-based charismatic Christian denomination Livets Ord (Word of Life or Ulf Ekman Ministries). Benny Hinn's ministry is popular in some parts of Christianity, but considered rather controversial in others. His personal moral standards, his theology and his alleged healings have been debated for several decades. Nevertheless, Livets Ord decided to invite him (for the sixth or seventh time, according to Ulf Ekman in Världen idag 21 July 2010), and in May 2010 the church announced his visit. This spurred a debate on the internet, where the matter was discussed on blogs and Twitter, primarily among Christian believers. Benny Hinn was scrutinized, his strengths and weaknesses were discussed, and Livets Ord's reasons for inviting him were targeted. This debate culminated on Twitter 
the weekend he held his services, and in the aftermath his participation was extensively discussed in the blogosphere. Benny Hinn's visit to Uppsala, and the online debate, never showed up in the mainstream media. The conference was streamed live online by Livets Ord's own TV production house, and an official hashtag was established for Twitter conversations. One could also follow the event through Livets Ord's blogs and their Facebook and Twitter accounts, channels in which discussion was encouraged.

This article will focus on describing and analyzing how the event was perceived and dealt with in the digital media, before, during and after the event. What is of particular interest here is how the digital media relocate the event - how this opens up a previously closed event, and potentially flattens out and questions traditional authorities. This is often said in relation to digital media in general, and in relation to the so-called social media more specifically (see for example the overview in Chong \& Ess 2012). The Benny Hinn debate gives us an empirical case to assess such claims. Without the digital media, Benny Hinn's appearance probably would have escaped the Swedish public eye, especially since Sweden is regarded as one of the most secular countries in the world.

This form of fervent debate is neither new nor solely related to digital or mass media. In this case the special dynamic came out of a mix between a controversial evangelist, the transparency which the digital media brought, and the novelty of this combination. The event appeared, according to Twirus.com, as a 'trending topic' on Twitter (in Sweden), and the most popular ('people that are most referred to by others') tweeps (Twitter users) that particular weekend related to the Benny Hinn event. It is interesting to note that a multitude of voices were involved in this discussion, which reached far outside the main core of people with an interest in these issues - i.e. people within the Christian sphere.

This article will not examine or evaluate Benny Hinn's theology, or to what extent the healings he claimed to perform actually took place, or if it was right or wrong to invite him - questions dealt with in the debate on the net. The article rather focuses on how the event became relocated or distributed in time and space through the use of digital media.

\section{Digital Religion - How the Media Change Structures}

Traditionally, the media of revivalist movements (and other popular movements such as the labor movement and the temperance movement) have functioned separately from the public sphere (in a Habermasian sense, 
Habermas 1989) - even though the aim has often been to reach out to the wider society (Furuland 1991, 268; Gelfgren 2003, 80-2). In this context, the sociologist of literature, Lars Furuland, talks about an alternative system for religious literature during the 19th and early 20th centuries, separated from the mainstream or the public sphere. These media, and their content, were in general produced, distributed and consumed within a closed system, mainly reaching people already involved in and committed to the cause. That is still the case today, especially in a secular country like Sweden. People reading the periodicals of the various churches and denominations, and watching or listening to services over radio or television, or people who join religious Facebook groups and following explicit Christian Twitter accounts, are to a large degree already Christians. (Hjarvard 2011, 132.)

In addition to a distinction between religious and mainstream media, commentators have also often assumed a division between communication in the digital media and in other spheres of communication. In previous research regarding religion and the digital media, there has been a tendency to dichotomize religion manifested and performed online and offline respectively. Christopher Helland, for example, in his influential work makes a distinction between 'online religion' and 'religion online' (Helland 2000; 2005). However, during the last few years the realm of the digital has become increasingly integrated into the everyday life of many people (in the wealthier parts of the world), and also into the work of churches and other established Christian structures (Hogan \& Wellman 2012, 49-50). It is no longer as relevant as before to uphold a solid distinction between the offline and the online, the analogical and the digital; instead, we can talk about a third space, where the digital and the physical meet, forming a new totality (cf. Campbell \& Golan 2011, 316-7).

Whereas books, newspapers, radio and television are all mass media with one sender and multiple receivers, the internet has to be seen as a mass-to-mass medium (for the first time in history), with multiple senders and receivers, as Manuel Castells notes (2003, 2-3). As a consequence, it is difficult to monitor who is 'sending' and receiving what, and the possibility to monitor what kind of material is being produced is also very limited. Instead of talking about a sender-receiver dichotomy between producers and consumers of media content, concepts such as producers, interactivity, networking, community building and user-generated content are emphasized (Bruns 2008; Jenkins 2008). The transparent, democratic and anti-hierarchical structures of the internet are features often seen positively in relation to the emergence of new ways to communicate, af- 
fecting religion, journalism or political upheavals, as in the Arab Spring of 2011. In other words, the internet potentially has the power to alter traditional structures of social authority (see for example Rheingold 2002; Ritter \& Trechel 2011).

The relationship between media and religion has been interpreted in three different ways, argue Cheong and Ess (2012, 14-8). One interpretation draws upon scholars such as Marshall McLuhan (1964) and Walter Ong (1982), claiming that the different media shape the message they transmit according to their specific characteristics. McLuhan famously claims along those lines that 'the medium is the message'. Another interpretation, following Stig Hjarvard's mediatization theory (2011), claims that religion is transformed by media institutions, because the growth of an autonomous media sphere in modern societies replaces religious institutions as the main mediator of religious faith and practises. Established institutions, including churches, must respond by adjusting their communication to fit the logic of the media. In this case, however, religion is a mere victim to circumstance, something Heidi Campbell rejects. In a third interpretation, she argues for an active 'religious-social shaping of technology' that emphasizes how religious actors can shape and adjust media technology to their purposes. Each attempt to use the media needs to be evaluated in relation to tradition, theology and the specific goals (Campbell 2010, 41-2).

The case specifically dealt with in this article cannot easily be described along any of these lines. On the whole, Livets Ord uses media successfully in outreach, both in Sweden and abroad, and they have one of the most advanced and elaborate strategies for their media presence strategies in the country. They have a pastor who blogs regularly, a web site with related Facebook and Twitter accounts, in-house TV production facilities, and their own publishing house for books, CDs and DVDs. On their website they write: 'In order to reach people beyond those who attend our meetings we have wide ranging activities through different media. Through the use of different media the Gospel can be preached independent of time and space.' Livets Ord is an experienced user of modern media, with a clear vision, using media to extend physical and temporal boundaries (cf. Cheong, Poon, \& Huang 2009, 294).

To a large extent, in fact, Livets Ord lives and thrives upon the strong use of media, following and understanding media logic, and thereby assenting to the processes described (or prescribed) by mediatization theory. Simultaneously, however, Livets Ord uses and shapes the media deliberately and consciously in line with Campbell's suggestions. In the past, they 
have shaped their use of the media according to their own ideology, but the Benny Hinn event shows how difficult it might be to fully control what is happening in the digital media.

\section{Source Material and Method}

This study draws upon collected blogs dealing with Benny Hinn during his stay in Uppsala, found through Google and by reading blogs linking to other blogs (all in all approx. 60 posts). All the tweets and blog entries have been translated into English by the author for this article. In addition to the blog posts, I have archived all tweets including the hashtag \#hinn10, retrieved through the Twapperkeeper.com service, from the two Sunday meetings on the 25th of July. I have read these blogs and tweets qualitatively to identify the general themes discussed, but I have also used Textometrica, a software tool developed by Simon Lindgren and Fredrik Palm at Umeå University for co-occurrence analysis (Lindgren \& Palm 2011), in order to visualize the network of tweeps (Twitter users), to see how they related and interacted with each other.

It is ethically problematic to use online material in a study like this, since there is an issue regarding what content should be considered private, and therefore unacceptable for research use without the producer's consent. I argue, however, that anything that is posted online and available through web pages and blogs can be considered as in the public domain, even though people posting online are not always conscious about this, and probably do not expect their material to appear in a research article. However, this kind of material can easily be retrieved through using common search engines such as Bing or Google and accessed without special login details. In some cases blogs or comments are no longer available, but I had saved electronic or paper copies before they were deleted. I have treated kind of material, too, as public in this research, and referred to it without seeking the authors' approval or making the authors anonymous.

Tweets are ethically somewhat more problematic. These messages are publicly accessible, and they are all stored by Twitter for a limited period, but they cannot be retrieved after this period has expired unless someone makes their own archive to save them. When I made my archives through TwapperKeeper, a tweet was automatically sent out on the \#hinn10 hashtag to say that I had done so, and I also posted a tweet and a blog post in which I described what I was doing (Gelfgren 2010a). Individual Twitter users have been made anonymous here, apart from public figures and media 
professionals (for example journalists or social media pundits) and users who also expressed their opinions through their blogs.

\section{Debate before the Benny Hinn Event}

In May 2010, Livets Ord proudly announced that Benny Hinn would open their annual 'Europe Conference'. Hinn's ministries had been characterized by 'the presence of the Holy Spirit', they declared, 'and many have experienced supernatural healing and miracles'. This would be the fifth time Hinn had visited Uppsala and Livets Ord (Livets Ord 2010). Hinn has been Ulf Ekman's personal friend since the 80s, and is consequently well known within the Livets Ord denomination.

On the 24th of May the Christian newspaper Världen idag (The World of Today - closely related to Livets Ord) presented the news in a neutral tone, describing how happy Livets Ord were to be able to engage Benny Hinn as a speaker (Världen idag 2010a). The first comments on this article were explicitly negative - 'Deeply tragic you're inviting Hinn!', and 'No, this is a fiasco!' - followed by another 37 comments discussing the advantages and disadvantages of the invitation. Commenters considered Hinn problematic for the following reasons: he seemed to be morally unstable after a recent divorce and a love affair; was preaching a dubious theology; was living a far too luxurious life; was offering people prayer and success if they send money to his ministry, and his alleged healings and salvations were considered suspicious. Positive voices among the commenters defended his activities and argued that any man can fall, only God can judge, and that Hinn had served God for many years. These different positions, with similar arguments, were to be repeated over and over again in the following debate.

The second major Swedish Christian newspaper, Dagen (The Day close to the Pentecostal movement), picked up the same announcement in a blog post the next day, including reflections upon comments made in the blogosphere. The conclusion made by Dagen's blogger and journalist Carl-Henric Jaktlund was that Livets Ord seemed unaware of the fact Hinn was a controversial and widely criticized figure (Jaktlund 2010). That post received 62 comments, with similar arguments to those expressed in the responses to the article in Världen idag mentioned above. One representative from Livets Ord, the head of PR, made an attempt to appease the critical voices by commenting on the Dagen post. 'Of course we know what we are doing', he said. 'The critique against Hinn is built upon rumors and speculations.' He then referred to Benny Hinn's own website in Hinn's support. 
This comment from Livets Ord was one of very few made by an official representative from Livets Ord on a web page outside their own channels.

However, this post by Livets Ord's representative was met with disbelief and counter-arguments. The critical commenters strengthened and supported their arguments with links to sources on the internet, including YouTube videos with and about Benny Hinn, web pages and blog posts scrutinizing Hinn and his activities, and TV programs and news features about him. These commenters on the Web use other web-based sources, just one click away for a reader, to support their arguments and to undermine Hinn's and Livets Ord's position. The Web gives commenters easy access to a whole range of supporting arguments and evidence, and thereby makes it difficult for anyone to be in control of the agenda of discussion, something that in general changes the potential for promoting one monolithic truth on the internet (compare with Campbell 2007). Online, truth is open to negotiation processes and relies upon the logic of the media - the only alternative might be to remove the discussion from the public eye.

Over the following two months, people (mainly within Swedish Christianity) continued to write blog posts about the forthcoming event. For example, one blogger, Kolportören, a pastor with a Swedish Free Church, wrote how disappointed he was with Livets Ord, since he thought they were recovering from these kinds of excesses, and then referred back to the 80s and the 90s when Livets Ord was more controversial. He linked to other bloggers and Dagen to find support for his opinion. (Elsander 2010a; 2010b) At maxa.nu another blogger was really happy and excited about Benny Hinn's visit, and said that Christians in Sweden should be more generous and less prejudiced. 'Last time [Hinn visited Uppsala] my son was healed, now he is prepared for another miracle' (Strindell 2010). The blogger Antropomorf took the opportunity to criticize Livets Ord and to question when they are going to ask for forgiveness for their infractions during the eighties and nineties (Laurin 2010). In several articles and blog posts it is not only Hinn who is under question; it is Livets Ord who is to blame for their dubious decision to invite him to open the conference. A couple of articles also appeared in Dagen (among them a critical leading article) and Världen idag.

What all these blog posts and newspaper articles have in common is that they are all written and published within an alternative/separate (Christian) public sphere, to use the terminology from Lars Furuland (1991). Online comments on these postings were also made by other Christians, referring mainly to other Christian web sources, such as blog posts and YouTube vid- 
eos. Nobody yet questioned the basic foundation of this alternative public sphere, Christianity itself, but that would also eventually come.

On the Tuesday before Hinn's visit, a message was posted to Forum för vetenskap och folkbildning (approx. Forum for Science and Popular Education, an association allied with the secularist movement in Sweden). A user and forum administrator placed a call asking if anyone was willing to accompany him to Uppsala for the Benny Hinn event, implying that there would be some disruptive activities going on (Forum för vetenskap och folkbildning 2010).

\section{During Hinn's Visit}

Benny Hinn held three meetings in Uppsala - one opening meeting on Saturday evening the 24th of July, a Bible study meeting on the Sunday morning, and one meeting with a healing session on the Sunday evening. They were all streamed live via Livets Ord's web page (now available on http://livetsordplay.se). From this weekend I have archived tweets from the alternative hash tag (\#hinn10) used during the Sunday meetings. This alternative tag emerged from a discussion on Twitter, focusing on Benny Hinn rather than the conference in general (which used \#ek10), according to a personal mail from one of the initiators. Most tweets tagged with \#hinn10 are also tagged with \#ek10. There are positive voices among those who tagged their tweets with the official tag \#ek10, but the critical utterances using both \#hinn10 and \#ek10 were also visible in the \#ek10 twitter feed.

At the time of writing, the two Sunday meetings on 26 July are still online to view through Livets Ord's own website. The first one on Saturday - a rather controversial exposition of Benny Hinn's theology - can no longer be found through Livets Ord. Hinn spoke for example about the nature of Jesus and of mankind, saying that Jesus was not eternal, but born of the Father, and also played down the human side of Jesus' nature. He talked about a human Trinity, where the body is a mere container to host the soul. After this exposition, Hinn was soon accused of Gnosticism in the blogosphere.

Ulf Ekman went up on the stage after Hinn's talk, asking people to ponder upon what Hinn had said. Ekman also responded to Hinn's teaching through the social media the day after. In a video blog the next morning (2010b) and in a blog post at Ulf Ekman's own blog (Ekman 2010a), he rejects parts of Hinn's teaching as 'speculative' and even partly 'heretical'. This must be recognized as an unusual countermove, and possibly intended to appease Hinn's critics. This direct response, through a modern medium, also illustrates how experienced Livets Ord is at handling and understanding 
an emerging media crisis. They were acting according to established media strategies - respond quickly and decisive and do not get into dialogue - trying to calm the debate and to set the agenda (Coombs 2007, 128-30).

The fact that Ekman was open with his critique was picked up both by the newspapers previously mentioned (Dagen and Världen idag) and in blogs. Världen idag mentioned Ulf Ekman's response to Hinn's preaching and also referred to the ongoing debate in the blogosphere (Världen idag 2010b). Ekman's blog post got 108 comments before the administrator, four days later, closed the post to further responses. Comments were both positive and negative, but notably Ulf Ekman himself did not contribute to the discussion.

The Twitter archive (\#hinn10 through Twapperkeeper.com) saved for this research contains 757 tweets posted between Sunday morning 25th July, just hours before the meeting, up until one week after the third meeting. Approximately 55 tweets were posted before the first Sunday meeting, 69 during Hinn's appearance on stage, 94 tweets between the meetings, and approximately 306 after Hinn's appearance during the last meeting. The most intense Twitter flow occurred during Hinn's final appearance on Sunday evening.

The first tweet in the archive, which read 'I've written the first draft of magic methods and psychological tricks', was posted a few days later to the blog En magisk blogg (Thunberg 2010). I myself published a blog post about Hinn, digital media and transparency - attracting the most readers of all the posts in my very modest blogging career (Gelfgren 2010b). Before the Sunday morning meeting, people were chatting on Twitter and preparing for the coming event, and talking about the meeting that had taken place the day before. These Twitter users sounded curious but slightly critical, sending messages like 'I'm prepared for the meeting', 'fingers crossed for a sound theology today', or 'maybe we were a bit too critical and judgmental yesterday'. Later, when Hinn was late for the meeting, people shared friendly jokes and one pastor told an old story about getting locked in a church bathroom and almost missing his service. During the meeting, one user noted that there was almost no 'strange' preaching from Hinn. One tweep admitted to one of Livets Ord's representatives that yes, there had been some 'throwing stones in glasshouses yesterday'. Tweets also included quotes and summaries from Hinn's preaching that morning, which attracted a more favorable response than he had received the day before. As someone concluded after the morning meeting: 'There was more preaching about Jesus today. Yesterday dealt with [...] other things.' Someone else 
thought the preaching was excellent, while another user claimed it was still too dualistic, referring to the meeting the day before. Posters engaged in this discussion appeared to be Christians, and mainly concerned with the theological content of Hinn's preaching.

After the end of the Sunday morning event, people started to anticipate the next meeting. As one put it: 'Things are heating up here at Twitter today.' Another asked for reviews: 'what kind of oddities were said [previously today], and what was good? Looking forward to tonight on Twitter.' Someone asks when the 'misery' will start again. One tweep, a Christian mentalist and also skeptic, said he wanted to be more focused on cunning tricks (his special area of competence), and less judging and cynical at the coming meeting, compared to the meeting before. One rather well-known person in the Swedish twittersphere showed up in the Twitter feed saying: 'Livets Ord is apparently open to constructive critique, please ask your question at their Facebook page'. A bit later the same tweep asked people to check out his Facebook group 'Children of sects', set up in collaboration with another well-known Swedish tweep and blogger. Yet another said 'I' $m$ thinking of how Livets Ord treated us 15 years ago. We who could not agree with everything and criticized and questioned instead', and continued in a second tweet that 'I carry my wounds - in the name of God and Ekman'. This message was re-tweeted by the same administrator who had made a call for disruptive action at the Forum för Vetenskap och folkbildning a few days before. When the last meeting started, a link to the video stream was posted on the secularists' forum. One of the more influential social media personalities in Sweden, with a background in the Church, decided to travel to Uppsala from Stockholm (one hour by train) to follow the final meeting on site, in order to make live reports via Twitter and his personal blog. People cheered his decision and gave him their support.

The temperature was now rising, and more and more voices got involved in the discussion. The most frequent Twitter user in the archive responded to the start of the last meeting on Sunday evening by analyzing the rhetoric of Livets Ord: 'They are psychologically building up the atmosphere right now. But I think you are aware of that.'

At the beginning of the evening meeting, most people just quoted Hinn and referred to the topics he was talking about. When Hinn talked about 'crusades', people on Twitter reacted that the concept of crusades had some problematic connotations. Someone said when he heard someone playing the organ like the musicians at Livets Ord, it made him think of ice hockey. Others responded to Hinn listing all the marvelous things he and 
his ministry had achieved, and how important their work was considered all around the world. One pastor critically wondered if anyone 'who has actually changed the world, like Mother Theresa and Martin Luther King, talked so much about their miracles'. As a reaction against all these negative remarks, one tweep noted that 'There are very few positive remarks here [on Twitter] tonight. It probably does not matter what Hinn is preaching', implying there was a general negative attitude in the Twitter feed.

The talk ended with an invitation to give money to Hinn's ministry. Hinn is quoted as saying: 'When you give for the sake of the Gospel you will be rewarded'. One Twitter user quickly replied that 'the theology of prosperity is showing its ugly face'. Another observed that 'this sowing and harvesting is old classic talk from the theologians of prosperity'.

When Hinn later urged parents to calm their children and keep them away from the aisles, several tweeps pointed out that Jesus said: 'Suffer the little children to come unto me', and that Hinn's anti-children theology is not supported by the Bible. When the service went into a more intense stage and people were invited on stage for healing, the activity on Twitter heated up as well, including criticism of Hinn's claim that sin and sickness are twins.

There were also a very few voices that were critical of the general negativity of the discussion on Twitter, saying things like: 'Wow, people have got opinions about when to sit down [...] Opinions are like assholes [...] everybody got one $[\ldots]$ ', and 'Twitter has now been silent for two minutes. No scandals to tweet?'

After about one and a half hours we can see people from the secularist movement (their affiliation with the movement is often stated in their Twitter biography) showing up in the Twitter feed, starting with the message, 'is this supposed to be god, or [what]?' The same tweep posted just a few minutes later that 'a thick layer ["hinna" in Swedish, a pun on Hinn's name] of disgust is covering Uppsala'. 'This is so boring, when are things starting to happen (I've been watching for three minutes)'. One of the skeptics tweeted 'religious cancer charlatanism' when Hinn talked about sickness and cancer, and another wrote, 'I'm quoting PZ Myers [a well known atheist] "Madness. Pure madness" ', and later 'I pity mankind' and 'just started watching. Now it is really uncomfortable. It feels dangerous.' Yet another said, 'Isn't it a bit sick we're spending a weekend evening watching a faith healer?', and someone else responded: 'The purpose is study, but of course we are exposed to potential work related damages [...]'. In someone else's opinion, 'It really hurts to see all the children in the congregation'.

So it continued. The frequency of tweets in the feed gradually increased. 
Some people were scrutinizing Hinn's theology, someone else was specifically studying alleged mental tricks, some were positively cheering for Jesus and Hinn, one referred to his 'fake healing' in the 90s, and others were just negative to everything happening. After a few minutes more people began 'popping in' to see what was going on, since they had seen the frequent use of the hash tags used (\#hinn10 and \#ek10) in their feeds. Someone tweeted '\#ek10 is trending right now'. One asked 'what is \#ek10 and \#hinn10', and 'so, what is actually \#hinn10 and \#ek10, and why are they taking up so much space in my twitter stream?'

During the healing session both skeptical and positive voices discussed the whole situation - some thanked God for what they have experienced, and some expressed hopes that the healings were real (implying they were a bit skeptical). On stage in Uppsala a woman claimed she had been cured from brain cancer. People were coming onto the stage, leaving their crutches, felt healing in their knees and necks, and a boy who had not spoken for years now spoke his first words. The healing session can still be seen on livetsordplay.se, about an hour and 20 minutes into the video stream.

After approximately two and a half hours the Sunday evening sessions ended. Ulf Ekman entered the stage, he gave thanks to Benny Hinn, and he also referred to social media, claiming that 'so much has happened that social media cannot keep up the pace'. Ekman was obviously aware of what was happening online during the meeting.

\section{Twitter in Quantitative Terms}

On the basis of the Twitter feed, we can note a few interesting aspects of the discussion. There are, as mentioned, 757 tweets by 133 different Twitter users in the \#hinn10 archive from the weekend around Hinn's visit to Livets Ord, according to Twapperkeeper's Summarizer statistics. The top 10 tweeps (7\%) account for $65 \%$ of all the tweets. Among them we find two journalists (one of them also a former pastor within the Pentecostal movement) reporting for the newspaper Dagen, one journalist with a more general interest in the whole event, one social media expert and journalist, one former Livets Ord member, the mentalist interested in mental tricks, one explicit supporter of Livets Ord, one pastor, and one skeptic.

The two top tweeps in terms of replies or mentions (which can be a sign of importance within the conversation) are the journalist/pastor and the social media expert. They were also the two 'most popular tweeps today' in Sweden this particular weekend, according to rates at Twirus.com. On this 
top-10 most popular list we also find Livets Ord's PR manager, Livets Ord and Benny Hinn. The Christian mentalist and the secular skeptic are also among the top 10. However, Livets Ord and Benny Hinn never reply, but since they are frequently addressed they are considered important.

Within the \#Hinn10-tag, Ulf Ekman was addressed 17 times, Livets Ord 18 times, and Benny Hinn 20 times - but none of them ever replied. Livets Ord sent one re-tweet about how to fix a problem with the stream service. The only official Livets Ord representative replying was the CEO, and he was addressed 27 times, but posted only five tweets (one reply), and never in reply to anything negative. Livets Ord's PR manager sent one re-tweet. Livets Ord's presence was, in other words, very weak among the archived tweets, rarely attempting to enter dialogue or offer a defense.

In order to study and visualize the structure of the discussion around the hash tag \#hinn10 the tweets in the archive were run through Textometrica (Lindgren \& Palm 2011) to check for co-occurrences - in other words to see who is mentioning and re-tweeting whom. The sender address was merged with the receiver and the rest of the tweet, marking the sender with $a_{-}$('avsändare'), the receiver with $m_{-}$('mottagare'), and re-tweets with $r t_{-}$. This identifies different categories of tweets (sender, receiver and re-tweets) and shows how often the different categories co-occur in the same messages. A tweet with no recipient (mention) or re-tweets does not show up in this schematic illustration. (See Figure 1.)

This gives us an understanding of how the different tweeps relate to each other, giving us an illustration of the whole network. The size of the nodes indicates frequency of mentions of one user, and the thickness of the arrow indicates frequency of messages between two nodes. If a circle is large, that specific node occurs in messages more often than a small circle. A user with a small $a_{-}$circle and a larger $m_{-}$circle has received more mentions then s/ he sent out (a characteristic of an 'important' tweep according to Twitter culture), and vice versa. Someone with a large $a_{-}$circle surrounded by many $r t_{-}$tags has posted many re-tweets.

As shown in the network, there is a central cluster around the Twitter users who are most active and also receive most attention in terms of mentions and re-tweets. The two most influential tweeps in Sweden that weekend (the Dagen journalist/pastor and the journalist/social media expert), according to Twirus.com, have larger $m_{-}$and $r t_{-}$circles than $a_{-}$circles. The two most active message senders have larger $a_{-}$circles then $m_{-}$and $r t_{-}$circles. Ulf Ekman, Livets Ord and Benny Hinn have only $m_{-}$circles, indicating they have only been addressed and never replied. 
Most of the other twitterers are distributed as nodes around the centre, indicating their rather low levels of activity. There are also a few 'islands' floating around the centre core, indicating that these small clusters are only interacting with each other. The extent to which they are reading and/or interacting on other Twitter topics or through other media is not visible in this diagram. The map also shows that the skeptics and secularists established their own, almost separate, structure of interaction. The secular skeptic among the top 10 twitterers appears as a focus for other skeptics and has rather large nodes within all three categories. Other skeptics and writers of critical tweets are found close to the nodes representing this skeptic individual. After reading through the tweets, one could get the impression that the skeptics were interacting in the larger field, but the diagram shows that their interaction is actually rather restricted to their own group.

\section{After Benny Hinn}

After the last service people stopped twittering as intensely, and returned instead to blogging their experiences and opinions regarding Benny Hinn and his appearance in Uppsala. Links to the blog posts were however distributed via Twitter, along with links to articles written in Dagen and Världen idag - both continuing to support their previous positions.

The day after the final meeting, these newspapers reported that Benny Hinn had a serious talk with his friends Ulf Ekman and Stanley Sjöberg (a leading personality within Swedish Pentecostalism). Both of them have known Hinn for a long time, apparently since the mid-80s (Ekman states that he has known him since 1986). According to Sjöberg, interviewed in Dagen and Världen idag, they talked about his life and the theological excesses shown during the meetings. It is reported that Hinn took their advice seriously (Dagen 2010c; Världen idag 2010d). These articles received several comments on the websites of the newspapers that published them.

In his blog posts published after Hinn's Bible exposition on the Saturday, Ekman appeared to be critical of Hinn's theology, but Livets Ord continued to come in for criticism in other blogs and their comment sections. Critics pointed out that the theology Hinn expressed during the Saturday meeting had been common teaching in Livets Ord and its Bible school during the $80 \mathrm{~s}$ and the 90s. Hinn's appearance had in fact reminded people of a time when Livets Ord was more controversial.

The most re-tweeted link on \#hinn10 directed readers to a blog post written by Emanuel Karlsten, a journalist and social media expert who at- 
tended the meeting in Uppsala. The blog post was somewhat critical, but written with compassion for all the people at the meeting who had been longing for healing but were not chosen (Karlsten 2010). In another, long blog post, the established Swedish Christian blogger and church leader, Stefan Swärd, offered an evaluation of Hinn, saying that he had been asked to publish a statement by people in the blogosphere. He tried to put Hinn in context, arguing that it is not that strange for an American televangelist to adopt the lifestyle Hinn is living. Little explicit critique was articulated in the post, and Swärd received many critical comments objecting that he was not being critical enough (Swärd 2010a). Two days later he posted another clarification about Hinn, and then a third the next day, both responding to this critique. (Swärd 2010b; 2010c).

Quite a few blog posts reminded Livets Ord that Hinn was known to be controversial, arguing that the church should have predicted the agitated public response to his appearance (for example Gembäck 2010; Isaksson 2010; Elsander 2010; Ordet 2010). Based upon the experience of Hinn's visit to Livets Ord, the blog Barnabasbloggen called for a more critical approach to all leadership within churches. (Melin 2010)

Other bloggers responded positively to Hinn and to what they had seen and experienced. The pastor at Pastor Tommys blogg, wrote that he and his wife had enjoyed every second of Hinn's 'power'. He wrote: 'Hinn has the power of an evangelist, and when I saw the final meeting I just wondered where the longing for the Holy Spirit, so present during the 90s, has gone'. He did not defend Hinn's luxurious life or his moral standards, but suggested that Swedish media focused too much upon problems. In his last sentence he proclaimed that the Holy Spirit will continue its work 'no matter what the social media believe' (Lilja 2010). The Bluefree blog was completely against Hinn and described his performance as self-deception and 'macabre acting'. (Bluefree Blog 2010)

At Forum för vetenskap och folkbildning (discussion thread Europakonferensen 2010, 20 July 2010-14 September 2010) some skeptics, also active at \#hinn10, concluded that they had seen a 'crazy show with miraculous healings, prophesies, and even exorcism'. One commenter posted an excerpt of a comment from Ulf Ekman's blog in which Ekman said that he was disappointed by the 'cynicism of the rally' going on on Twitter. 'Not even Jesus could have stood the critique there. Every little detail was scrutinized, instead of following the meeting as a whole.' One person at the secularists' forum observed that: 'it seems like our evil agenda succeeded'. This implies at least some intention, or loose plan to collaborate, to disturb the Uppsala event. 
The blog Antropomorf highlighted the problems that Livets Ord had encountered as a consequence of their web presence and the new transparency that this brings. He had put several critical questions to Livets Ord, who encouraged dialogue through social media (mainly Twitter and Facebook), but had received no reply. He argued that the social media support interaction and two-way dialogue, but that Livets Ord try to use the social media as a one-way channel of communication without understanding the consequences. (Laurin 2010a) An alternative perspective, based on media crisis strategies, might be that Livets Ord did fully understand the logic of the social media and had chosen not to be involved in such a discussion as part of a well-planned media strategy.

Online discussion of Hinn's speeches spread internationally. The author of the Swedish blog Aletheia translated one of Ulf Ekman's blog posts into English, selecting the post in which Ekman described Hinn's preaching as heretical but also defended him. Among the comments on Aletheia's translation we find a message from the Aletheia blogger himself, reporting that he had received an email from Livets Ord's PR manager requesting him to remove the translation on the grounds of copyright infringement. When Aletheia refused, the PR manager sent another email, published in full on Aletheia's blog: 'I understand your point, but please remove the translation'. (Aletheia 2010) This attempt to block the English translation of Ekman's blog was not well received among other commenters, who encourage Aletheia to stand strong against Livets Ord.

\section{Digital Media, Transparency and Dissolving Boundaries}

The digital media have the potential to break down established power structures, due to the openness, transparency, plurality and interactivity which characterizes them. In this case study, the online discussion (mainly in blogs and on Twitter) of a guest appearance in Sweden by the American televangelist Benny Hinn has been examined. Through streaming the events, Livets Ord opened up a previously often closed event to the public, but by doing so also lost absolute control over the event. Various voices were involved in the debate - from overtly positive ones to outspoken critics. It is however also clear how a central core of participants discussed the event among themselves, while the main critics and occasional participants were also clustered among themselves, with only limited overlap between these distinct circles. On the other hand, Livets Ord, the church responsible for hosting the event, played a relatively minor role in the online discussion, despite its openness to using the digital media. 
When they leave the familiar environments of the older analogical media - limited in time, space and audience - the churches find themselves operating in and experiencing a new and unfamiliar context. The transition to the digital media has raised both hopes and concerns, and the range of literature designed to help churches take the leap is extensive (see books such as Baily \& Storch 2007; Wilson \& Moore 2008). Through the use of digital media, the churches are both attempting to reach out to new audiences, and hoping to provide improved support for their adherents in their everyday lives, beyond the meetings and activities hosted in their physical church buildings. However, entering the digital era is not always unproblematic or straightforward. Issues related to identity, community and authority all come under negotiation (Barker 2005, 74; Cheong \& Ess 2012, 9-18). Similar mechanisms are at work elsewhere too, where knowledge is 'produced' (see for example Bruns 2008 on participatory culture and collaborative knowledge production).

In Western societies in modern times, the churches and their media discourse have typically occurred in media environments increasingly separated-off from the public sphere, which is to some extent predicated by the ways in which a modern, secularized society functions. What is going on within the church has been seen as an internal affair, mainly involving people with special interest in church activities. The literature on churches and modernity is vast; see for example Taylor (2007) for a recent and extensive account of the subject. The social media, however, offer the churches a new means to attempt to dissolve these boundaries between the church and public communication spheres.

The specific case dealt with here shows another side to this new reality. If they had not chosen to stream the event online, Livets Ord could probably have invited even a controversial evangelist like Benny Hinn without attracting much attention beyond the Christian press. Opening the event to new media provided fuel for a print and online debate that began on the day Livets Ord announced Hinn's invitation, and carried on for weeks after the event. These discussions reached their climax on Twitter during Hinn's final meeting and thereafter slowly declined. A wide range of voices were heard in the debate - applauding the boldness of the invitation, expressing concern, and showing disdain for Hinn's character and theology. The resulting debate placed pressure on the leadership of Livets Ord to respond to this public discussion and defend their actions, although they responded only to a very limited extent. The morning after Hinn's first (controversial) meeting, Ulf Ekman declared his point of view 
in a blog post on his blog and also through a video blog. Livets Ord chose not to participate in the debate collectively as an organization, communicating almost exclusively through their own media channels. A small number of attempts to communicate directly with critics through blog comments proved rather unsuccessful.

This article does not attempt to determine whether Livets Ord's decisions were wise or not, but merely notes that this strategy is in line with textbook cases on how to deal with emerging scandals in the media. Media strategists typically suggest that in an emerging crisis, a quick response will be the best move to set the agenda from the organization's point of view. It also gives both the media and stakeholders the impression of retaining control. Moreover, a rapid reply also shows that the organization is capable of handling a crisis (Coombs 2007, 144-6). On the internet and in the social media, however, the advice is to proceed cautiously, since the debate may involve persons who wish to harm you as an organization. So, according to for example Kenton, at scenes from the superhighway (Kenton 2008): 'do not get dragged into an argument, or a back-and-forth debate about who is right. In most cases, you won't win an argument with a customer in terms of public perception'; and 'if the crisis is emerging on a fast moving network like Twitter or Facebook, your best option is to create a fact page that you can post either on your blog, or as a web page. Engage your employees who are on Twitter or Facebook to post a link to your fact page.' In other words - if you want to hold on to your agenda, do not get too involved in social media outside your own control.

Cheong and Ess $(2012,14-5)$ suggest that there has been a tendency to associate religious authority offline 'with more static models of legitimation', whereas the internet is characteristically seen 'as promoting informational diversity and social fractures that are disruptive to the status quo'. The truth is probably more complex, and lies somewhere in between. Even if it is difficult to make firm judgments about online authority in relation to offline, Cheong and Ess say that 'at the same time, in part just as new and social media challenge - as promised - traditional hierarchies and patterns of authority, religious leaders are caught up in an often complex and dynamic process of re-negotiating the authority they now seek to exercise in online, as well as offline, spheres, including possibly new institutional structures'. This is what we see here. Although Livets Ord and their representatives engage with the online community only to a limited degree, they are well aware of what is happening, and also refer to the discussion online, directly at the meetings and in blog and video posts. 
When Benny Hinn spoke at the first meeting, he offered a somewhat controversial interpretation of the Bible. This was quickly picked up by bloggers, tweeps, and also in the newspaper Dagen, suggesting that his approach was unorthodox, and even Gnostic. The next day, Ulf Ekman published a video and a text blog post in which he offered his own critique of Hinn. Nonetheless, Ekman never referred here to what was going on at the same time on the internet. However, in the comments on his blog post, individuals friendly to Livets Ord referred critically to the social media debate, accusing bloggers and Twitter users of being cynical and too quick to judge things they don't know enough about. 'It seems like the Inquisition has reappeared and a heretic's pyre has been lit for Benny Hinn, if you read blogs', one comment claimed. Världen idag, the newspaper close to Livets Ord, published an article reporting on Ulf Ekman's critique of Hinn, claiming that 'the majority of the blogosphere is critical to the Saturday evening preaching' (Världen idag 2010b). Two days after Hinn's Sunday meetings, one of the Världen idag's bloggers accused fellow Christians active on the social media during the Hinn event of abandoning common sense and Christian sense, and suggested that this is emblematic of the status of faith in Sweden (Världen idag 2010c).

One sign of the new openness or transparency facilitated by the digital media was the participation in the ongoing discussion of skeptics, recruited via one of their own forums. Analysis of the networking of posted tweets, however, reveals that the skeptics mostly interacted with each other, and that their posts were rarely picked up by the majority of Twitter users. Their tweets do however seem to have alerted other people to check out what was going on. Following the Twitter feed, it is apparent that the success of the \#hinn10 and \#ek10 tags attracted wider attention among other tweeps. The tags were 'trending topics' during that particular weekend, and after a while other people noticed the tags in their feed and started asking questions about the event. Apparently at least some of them also checked out the live video stream.

Apart from some critical articles in Dagen looking for empirical evidence of Hinn's alleged miracles (for example Dagen 2010a), the whole debate evolving around the invitation of Benny Hinn was fueled by evidence found online. In other words, 'the Internet offers a new content to the available knowledge', as Barker puts it, and suggests that thereby the internet can contribute to undermining any single truth $(2005,74)$. Critical comments often directed people toward reading or watching other online sources. There are for example several videos of Hinn preaching on YouTube, includ- 
ing some that support a critical or negative view of his ministry. One video sequence on YouTube, appearing among the links posted to the \#hinn10 Twitter hashtag, shows Hinn explicitly cursing anyone who questions his authority. There is also a video clip showing him on a shopping spree in Beverly Hill, and there are links to pictures and reports from Hill's alleged love affair, critical reports from American national television, a documentary attacking Hinn's ministry, and so on.

Livets Ord's own representatives commented on the discussion only twice outside their own media channels. One of these occasions was a comment by Livets Ord's PR manager on a blog post written by one of Dagen's bloggers (Jaktlund 2010). The PR manager wrote that much criticism was founded upon 'rumors and speculations', and he met some of the critique regarding Hinn's business affairs by linking to Hinn's own webpage. In the same comment, he also said that 'of course we are aware of Hinn's divorce, but that is something we don't comment on in the media'. Some of the comments on what the PR manager said question the reliability of Hinn's site, and one also links to a CBS News report as a counter reference, and as a more objective source of information. In these messages, the authority of Benny Hinn and Livets Ord is undermined, by cross-checking their statements against other sources and encouraging a wider debate that includes different perspectives.

This case study thus explores how a church event can be impacted by the openness to wider debate potentially created by the social media and an online video stream. The author of one leading article in Dagen, the day after the Benny Hinn event, concluded: 'The whole Benny Hinn debacle has damaged Swedish Christianity in many ways. The sad thing is that it was really unnecessary' (Dagen 2010b). Determining how best to evaluate the long-term impact of this openness on the religious sphere in Sweden is beyond the scope of this article. However, this study does show that many people outside Livets Ord believed that the established power structures within Swedish Christianity had been shaken by the powers of public dissent facilitated by the social media.

One crucial voice is missing from this analysis, however, and that is Livets Ord's. Livets Ord was the top centre of attention on Twitter in Sweden during this event, but the public sources used in this study do not allow us to know how Livets Ord itself experienced this particular weekend. It might be the case that external critique actually strengthens the identity of believers within the Livets Ord movement, and even helps the denomination attract new adherents and supporters. Further study would be needed 
to form a more complete picture of the long-term effects of Benny Hinn's visit to Uppsala.

\section{Bibliography}

Video stream

Jesus är läkaren, 25 July $2010<$ http://livetsordplay.se/play.aspx?idClip=3168 \&cn=Europakonferens>, accessed 2 December 2011.

Blogs, forums and web pages

\section{Aletheia - Blogg \& Tankesmedja}

2010 Ulf Ekman about Benny Hinn: Heretical view of Jesus presented - Aletheia - Blogg \& Tankesmedja, 27 July $2010<$ http://aletheia.se/2010/07/27/ ulf-ekman-about-benny-hinn-heretical-view-of-jesus-presented/ comment-page-1/\#comment-171378>, accessed 2 December 2011.

\section{Bluefree's blogg}

2010 Förmågan till självbedrägeri - Bluefree's blogg, 26 July $2010<\mathrm{http}: / /$ bluefree.wordpress.com/2010/07/26/formagan-till-sjalvbedrageri/>, accessed 2 December 2011.

\section{Ekman, Ulf}

2010a Benny Hinns besök - Ulf Ekman.nu, 26 July $2010<$ http://ulfekman. nu/2010/07/26/benny-hinns-besok/>, accessed 2 December 2011.

2010b Ulf Ekmans videoblogg från Europakonferensen, dag 1 - Ulf Ekmans videoblogg, 26 July $2010<$ http://www.youtube.com/watch?v=5rqhLIT Jw3w\&feature=player_embedded $>$, accessed 2 December 2011.

\section{Elsander, Joakim}

2010a Ett unikt tillfälle för Livets ord. Benny Hinn del två - Kolportören, 27 May $2010<$ http://www.kolportoren.com/2010/05/ett-unikt-tillfallefor-livets-ord.html $>$, accessed 2 December 2011.

2010b Suck! Benny Hinn kommer till Livets Ord - Kolportören, 27 May 2010 $<$ http://www.kolportoren.com/2010/05/suck-benny-hinn-kommertill-livets-ord.html>, accessed 2 December 2011.

2010c Nu släpper jag Benny Hinn med: 'Vad var det jag sa' - Kolportören, 30 July $2010<$ http://www.kolportoren.com/2010/07/nu-slapper-jagbenny-hinn-med-vad-var.html $>$, accessed 2 December 2011. 


\section{Forum för vetenskap och folkbildning}

2010 Europakonferensen 2010 - Forum för vetenskap och folkbildning, 20 July 2010-14 September $2010<$ http://www.vof.se/forum/viewtopic. php?f=38\&t=13051>, accessed 2 December 2011.

\section{Gelfgren, Stefan}

2010a Arkivering av tweets från Benny Hinns sverigebesök. - Churchandinternet Blog, 30 July $2010<\mathrm{http}: / /$ churchandinternet.wordpress. com/2010/07/30/arkivering-av-tweets-fran-benny-hinns-sverigebesok/>

2010b Livets Ord, Benny Hinn och den digitala offentligheten - Churchandinternet Blog <http://churchandinternet.wordpress.com/2010/07/25/ livets-ord-benny-hinn-och-den-digitala-offentligheten/>, accessed 2 December 2011.

\section{Gembäck, Peter}

2010 Anmärkningsvärt!!! - Peter Gembäcks tankar och funderingar!, 26 July $2010<$ http://petergemback.blogspot.com/2010/07/anmarkningsvart. html $>$, accessed 2 December 2011.

\section{Isaksson, Bernt}

2010 GB: Summering av Hinns besök av Berndt Isaksson - Erevna - Blogg $\mathcal{E}$ Tankesmedja <http://erevna.nu/?p=2287>, accessed 2 December 2011.

\section{Jaktlund, Henrik}

2010 Svårt bedöma Benny Hinn på distans - Jaktlunds marginalanteckningar, 25 February $2010<$ http://www.dagen.se/blogg/jaktlund/2010/05/ svart-bedoma-hinn-pa-distans>, accessed 2 December 2011.

\section{Karlsten, Emanuel}

2010 En kväll med Benny Hinn - Emanuels randanmärkningar, 26 July 2010 $<$ http://emanuelkarlsten.se/07/en-kvall-med-benny-hinn/>, accessed 2 December 2011.

\section{Kenton, Chris}

2008 Crisis Management Essentials for Social Media (Part 2) - Scenes from the superhighway, 18 December $2008<\mathrm{http}: / / \mathrm{www}$.chriskenton. com/2008/12/crisis-management-essentials-for-social-media-part-2. html>, accessed 13 February 2012.

\section{Laurin, Christopher}

2010a Den transparenta trosrörelsen - antropomorf, 6 July $2010<\mathrm{http}: / /$ antropomorf.se/2010/08/06/den-transparenta-trosrorelsen/>, accessed 2 December 2011.

2010b Har Livets Ord ändrat sig? - antropomorf, 21 July $2010<$ http://antropomorf.se/2010/07/21/har-livets-ord-andrat-sig/>, accessed 2 December 2011. 


\section{Lilja, Tommy}

2010 Benny Hinn i toppform, Ekman berusad av Anden - Pastor Tommys Blogg, 26 July $2010<$ http://pastortommys.blogspot.com/2010/07/benny-hinn-i-toppform-ekman-berusad-av.html>, accessed 2 December 2011.

\section{Livets Ord}

2010 Benny Hinn inleder Europakonferensen <http://www.livetsord.se/default. aspx?idStructure=10094>, accessed 2 December 2011.

\section{Melin, Jonas}

2010 Hur prövar man en andlig tjänst? - Barnabasbloggen, 27 July 2010 $<$ http://barnabasbloggen.blogspot.com/2010/07/hur-provar-man-enandlig-tjanst.html>, accessed 2 December 2011.

Ordet...

2010 Vem är Benny Hinn? - Ordet..., 29 July $2010<$ http://ordetvargud. blogspot.com/2010/07/vem-ar-benny-hinn.html>, accessed 2 December 2011.

\section{Strindell, Niclas}

2010 Oerhört roligt med Benny Hinn på Europakonferensen! - maxa. nu, 9 June $2010<$ http://www.maxa.nu/allmant/oerhort-roligt-medbenny-hinn-pa-europakonferensen/993/comment-page-1/>, accessed 2 December 2011.

\section{Swärd, Stefan}

2010a Vad jag tycker om Benny Hinn - Stefan Swärd - Allt mellan himmel och jord, 26 July 2010 <http://www.stefansward.se/2010/07/26/vad-jagtycker-om-benny-hinn/>, accessed 2 December 2011.

2010b Rond 2-i Benny Hinn debatten - nu bemöter jag mina kritiker - Stefan Swärd - Allt mellan himmel och jord, 27 July $2010<$ http://www.stefansward.se/2010/07/28/rond-2-i-benny-hinn-debatten-nu-bemoter-jagmina-kritiker/>, accessed 2 December 2011.

2010c Hinn-debatten rond 3, försök till svar på frågor - Stefan Swärd Allt mellan himmel och jord, 29 July $2010<$ http://www.stefansward. se/2010/07/29/hinn-debatten-rond-3-forsok-till-svar-pa-fragor/>, accessed 2 December 2011.

\section{Thunberg, Samuel Varg}

2010 En vitkalkad grav II - En magisk blogg, 27 July $2010<$ http://iloapp. samuelvargthunberg.se/blog/blogg?Home>, accessed 2 December 2011.

Newspaper articles

\section{Dagen}

2010a Benny Hinns mirakel är svåra att bevisa ... och Ulf Ekman vill inte för- 
svara hans lyxliv, 22 July $2010<$ http://www.dagen.se/dagen/article. aspx?id=219648>, accessed 2 December 2011.

2010b En irrlärare på Livets ord, 28 July $2010<$ http://www.dagen.se/dagen/ article.aspx?id=220211>, accessed 2 December 2011.

2010c Sjöberg: Hinn är ledsen över sina uttalanden , 29 July $2010<\mathrm{http}: / / \mathrm{www}$. dagen.se/dagen/article.aspx?id=220452>, accessed 2 December 2011.

Världen idag

2010a Benny Hinn till Livets ords Europakonferens, 24 May $2010<\mathrm{http}$ :// www.varldenidag.se/nyhet/2010/05/24/Benny-Hinn-till-Livets-ordsEuropakonferens $>$, accessed 2 December 2011.

2010b Ulf Ekman kritisk till Benny Hinns predikan 26 July $2010<\mathrm{http}: / / \mathrm{www}$. varldenidag.se/nyhet/2010/07/26/Ulf-Ekman-kritisk-till-BennyHinns-predikan/>, accessed 2 December 2011.

2010c Teologisk analys efterlyses, 28 July $2010<$ http:/www.varldenidag.se/ blogg/2010/07/28/Teologisk-analys-efterlyses/>, accessed 2 December 2011.

2010d Benny Hinn inser felformulering, 29 July $2010<$ http://www.varldenidag. se/nyhet/2010/07/29/Benny-Hinn-inser-felformulering>, accessed 2 December 2011.

Books and articles

Baily, Brian \& Terry Storch

2007 The Blogging Church: Sharing the Story of Your Church Through Blogs. San Francisco, CA: Jossey Bass.

\section{Barker, Eileen}

2005 Crossing the Boundary: New Challenges to Religious Authority and Control as a Consequence of Access to the Internet. - Morten T. Højsgaard \& Margit Warburg (eds), Religion and Cyberspace, 67-85. London: Routledge.

Bruns, Axel

2008 Blogs. Wikipedia. Second Life. and Beyond. New York: Peter Lang Publishing.

\section{Campbell, Heidi}

2007 Who's Got the Power? Religious Authority and the Internet - Journal of Computer-Mediated Communication, 12 (3), article 14. < http://jcmc. indiana.edu/vol12/issue3/campbell.html >, accessed 10 November 2010.

2010 When Religion Meets New Media. London: Routledge.

\section{Campbell, Heidi \& Oren Golan}

2011 Creating Digital Enclaves: Negotiation of the Internet Among Bounded Religious Communities - Media, Culture E Society 33 (5), 709-24. 


\section{Castells, Manuel}

2003 The Internet Galaxy: Reflections on the Internet, Business, and Society. Oxford: Oxford University Press.

\section{Cheong, P. H. \& J. P. H. Poon \& S. Huang}

2009 The Internet Highway and Religious Communities: Mapping and Contesting Spaces in Religion-Online - The Information Society 25 (5), 291-302.

\section{Cheong Hope, Pauline \& Charles Ess}

2012 Introduction: Religion 2.0? Relational and Hybridizing Pathways in Religion, Social Media, and Culture. - Pauline Cheong \& Peter FisherNielsen \& Stefan Gelfgren \& Charles Ess (eds), Digital Religion, Social Media and Culture: Perspectives, Practices and Futures, 1-21. New York: Peter Lang Publishing.

\section{Coleman, Simon}

1991 Livets Ord och det Svenska Samhället: Analys av en Debatt. - Tro och tanke (4), 27-83. Uppsala: Swedish Church Publications.

1993 Conservative Protestantism and the World Order: The Faith Movement in the United States and Sweden - Sociology of Religion 54 (4), 353-73.

\section{Coombs, W. Timothy}

2007 Ongoing Crisis Communication: Planning, Managing, and Responding. Los Angeles: SAGE.

\section{Estes, Douglas}

2009 SimChurch: Being the Church in the Virtual World. Grand Rapids, MI: Zondervan.

\section{Friesen, Dwight J.}

2009 Thy Kingdom Connected: What the Church Can Learn from Facebook, the Internet, and Other Networks. Grand Rapids, MI: Baker books.

\section{Furuland, Lars}

1991 Ljus över landet och andra litteratursociologiska uppsatser. Hedemora: Gidlunds bokförlag.

\section{Gelfgren, Stefan}

2003 Ett utvalt släkte: Väckelse och sekularisering - Evangeliska FosterlandsStiftelsen 1856-1910 Skellefteå: Norma förlag.

\section{Habermas, Jürgen}

1989 The Structural Transformation of the Public Sphere: An Inquiry into a Category of Bourgeois Society. Cambridge, Mass.: MIT Press. 


\section{Helland, Christopher}

2000 Religion Online/Online Religion and Virtual Communitas. - Jeffery K. Hadden \& Douglas E. Cowan (eds), Religion on the Internet: Research Prospects and Promises, 205-24. London: JAI Press/Elsevier. Science.

2005 Online Religion as Lived Religion: Methodological Issues in the Study of Religious Participation on the Internet - Online - Heidelberg Journal of Religions on the Internet 1 (1). < http://archiv.ub.uni-heidelberg.de/ volltextserver/volltexte/2005/5823/pdf/Helland3a.pdf $>$, accessed 25 August 2010.

\section{Hjarvard, Stig}

2011 The Mediatisation of Religion: Theorising Religion, Media and Social Change - Culture and Religion, 12, 119-35.

\section{Hogan, Bernie, \& Barry Wellman}

2012 The Immanent Internet Redux - Pauline Cheong \& Peter FisherNielsen \& Stefan Gelfgren \& Charles Ess (eds), Digital Religion, Social Media and Culture: Perspectives, Practices and Futures, 43-62. New York: Peter Lang Publishing.

\section{Jenkins, Henry}

2006 Convergence Culture: Where Old and New Media Collide. New York: New York University Press.

\section{Lindgren, Simon \& Fredrik Palm}

Textometrica Service Package - < http://textometrica.humlab.umu.se/ >, accessed 1 October 2010.

\section{McLuhan, Marshal}

1964 Understanding Media: The Extensions of Man. London: Routledge.

Ong, Walter J.

1982 Orality and Literacy: The Technologizing of the Word. London: Methuen.

\section{Rheingold, Howard}

2002 Smart Mobs : the Next Social Revolution. Cambridge, Mass.: Perseus Pub.

\section{Rice, Jesse}

2009 The Church of Facebook: How the Hyperconnected Are Redefining Community. Colorado Springs, CO: David C Cook Publishing Company.

\section{Ritter, Daniel. P. \& Alexander H. Trechsel}

2011 Revolutionary Cells: On the Role of Texts, Tweets, and Status Updates in Nonviolent Revolutions. Paper presented at the conference on 'Internet, Voting and Democracy', Laguna Beach, California May 14-15 2011. < http://www.democracy.uci.edu/files/democracy/docs/ conferences/2011/Ritter_Trechsel_Laguna_Beach_2011_final.pdf>, accessed 7 January 2012. 


\section{Sjödin, Ulf}

2001 Mer mellan himmel och jord?: En studie av den beprövade erfarenhetens ställning bland svenska ungdomar. Stockholm: Verbum.

\section{Skog, Margareta}

2001 Det religiösa Sverige: Gudstjänst- och andaktsliv under ett veckoslut kring millennieskiftet. Orebro: Libris.

\section{Taylor, Charles}

2007 A Secular Age. Cambridge, Mass.: Belknap Press of Harvard University Press.

Wilson, Len \& Jason Moore

2008 The Wired Church 2.0. Nashville, TN: Abingdon Press. 
Appendix. Figure 1. The visualization of the \#hinn10 network made with Textometrica. It is a centre-weighted network with the main activities going on in the middle of the picture. The secularists are gathered at the bottom right corner of the picture. See page 95 for the discussion related to the diagram.

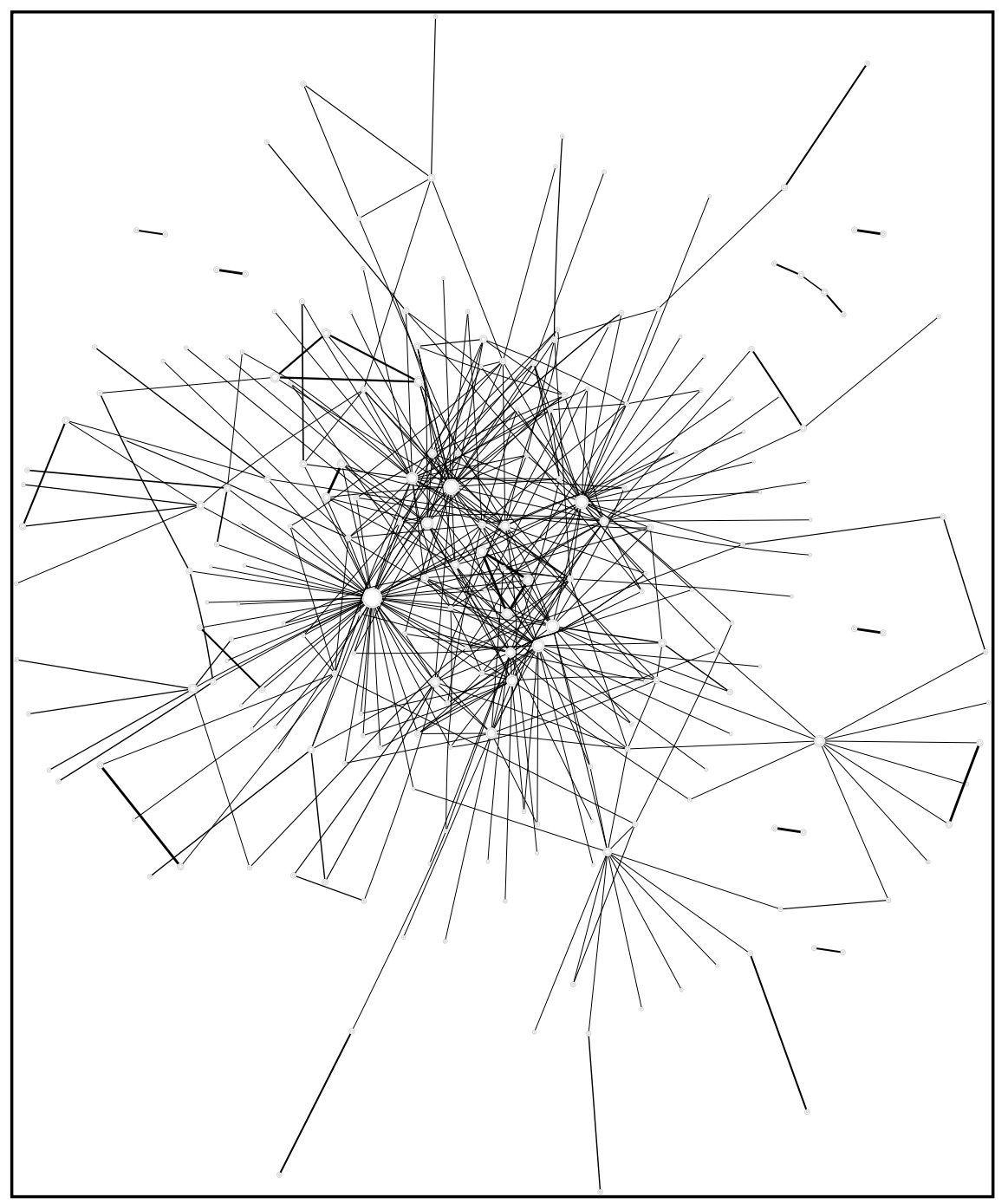

